Proc. Indian Acad. Sci. (Earth Planet. Sci.), Vol. 100, No. 3, September 1991, pp. 281-291.

(C) Printed in India.

\title{
Coexisting pyroxenes from the basic granulites of Visakhapatnam area in the Eastern Ghats terrain
}

\author{
A T RAO, J U RAO*,A MADHAVA RAO and P CH SANJEEVA RAO** \\ Department of Geology, Andhra University, Waltair 530003 , India \\ * Present address: Geological Survey of India, Ratnakar Building, 4-Chowranghee Lane, \\ Calcutta 700016, India \\ **Geology Department, Nagarjuna University, Nagarjuna Nagar 522510 , India \\ MS received 11 August 1990; revised 13 May 1991

\begin{abstract}
Fifteen pairs of coexisting pyroxenes from basic granulites associated with leptynites in the khondalite suite of rocks are analysed and the distribution of $\mathrm{Mg}$ and $\mathrm{Fe}^{2+}$ ratios is presented. Temperature estimates for the coexisting pyroxenes from the basic granulites of Visakhapatnam may be expressed as $750 \pm 100^{\circ} \mathrm{C}$ corresponding to intermediate pressure granulites.
\end{abstract}

Keywords. Coexisting pyroxenes; basic granulites; granulite terrain.

\section{Introduction}

Mineralogical thermometers and barometers have been widely used to estimate pressure and temperatures in high grade metamorphic rocks for various mineral assemblages.

Coexisting pyroxenes are believed to be important and interesting rock-forming minerals (Kretz 1982; Fonarev and Graphchicov 1987) which provide information on the physico chemical conditions. Pyroxene minerals are essential constituents in the basic granulites that occur in the Eastern Ghats granulite terrain (figure 1). The basic granulites are widespread and exposed in the leptynites of the khondalite suite of rocks in Visakhapatnam area, Andhra Pradesh. These are cofolded and inolved in the same deformation as those of leptynites and khondalites. Halden et al (1982) recognized four phases of deformation and three metamorphic events in the Eastern Ghats belt of Orissa. The regional structural set-up of Visakhapatnam showing folded and refolded structures and accompanying high grade and retrograde metamorphic mineral assemblages was reported by Sriramdas and Rao (1979). The corresponding ages of $(2,600 \mathrm{my}$ and 2,000 my: $\mathrm{Rb}-\mathrm{Sr}$ method) metamorphism are inferred from the published data (Perraju et al 1979) in the Visakhapatnam region. The mafic granulites from Visakhapatnam district gave an Sm-Nd model age 2,860 my (Paul et al 1990) suggesting that the mafic granulites were intruded into the khondalite suite of rocks and subsequently involved in deformational and metamorphic episodes. The leptynites (garnetiferrous granites) associated with basic granulites in Visakhapatnam are characterized by garnet \pm sillimanite-spinel assemblage and the $P-T$ parameters correspond to $800^{\circ} \mathrm{C} \pm 100^{\circ} \mathrm{C} / 8 \mathrm{kbars}$ (Rao and Rao 1987). The basic granulites are of gabbroic composition and clinopyroxene dominates over orthopyroxene. The 


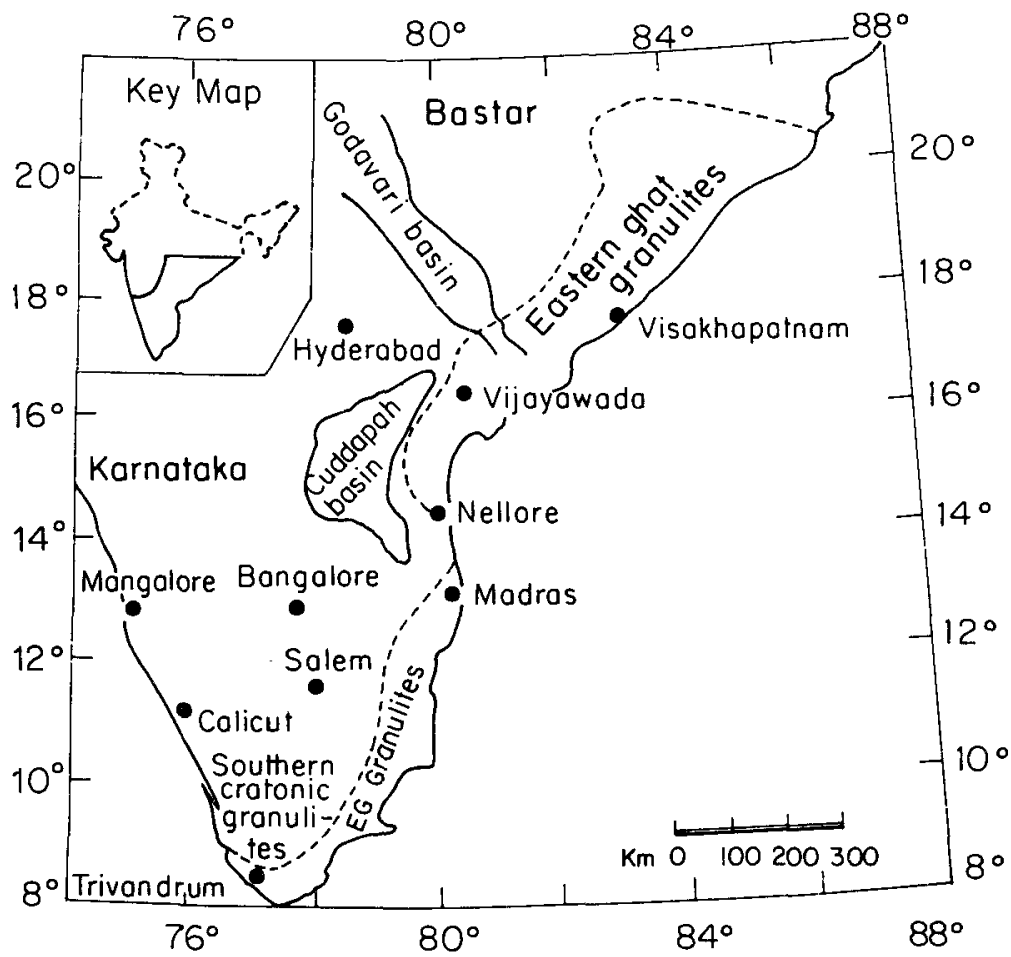

Figure 1. Map showing the extension of granulite belt in South India.

present study of coexisting pyroxenes attempts to establish temperature conditions of metamorphism in the area.

\section{Chemical data}

\subsection{Orthopyroxenes}

The data of the analysed orthopyroxenes (tabel 1), when referred to the diagram of Hess (1952) modified by Deer et al (1963), indicate that the orthopyroxenes range from hypersthene to ferrohypersthene in composition. The $\mathrm{Al}_{2} \mathrm{O}_{3}$ ranges between 1 and $3 \%$ by weight. When compared to the analyses reported earlier (Howie 1955; Leelanandam 1967), $\mathrm{Al}_{2} \mathrm{O}_{3}$ is relatively low. The amount of aluminium in the $Z$ group is also variable and is always greater than that in the $X$ group. This is a common observation in most of the orthopyroxenes of basic granulites.

\subsection{Clinopyroxenes}

The data of the analysed clinopyroxenes (table 2) when extrapolated in the diagram of Hess (1949) and later slightly modified by Muir (1951), indicate that clinopyroxenes fell in the salite and augite fields (figure 2). 


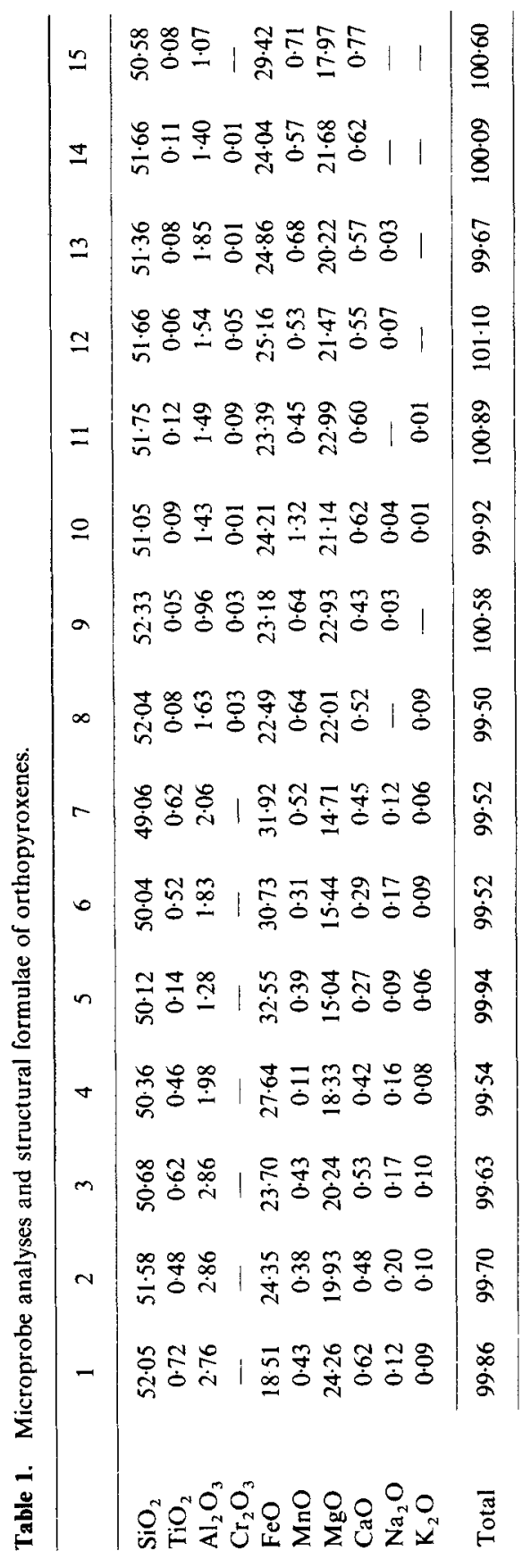

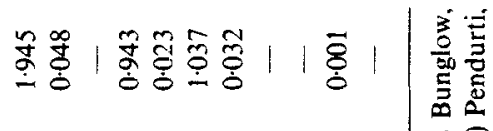

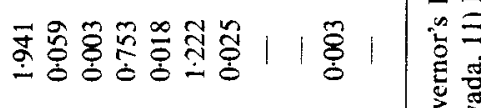

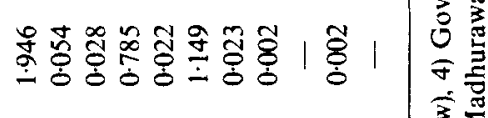

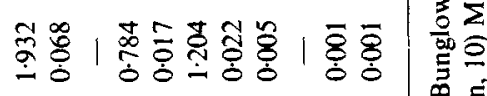

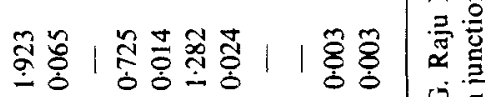
ํ.

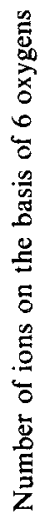

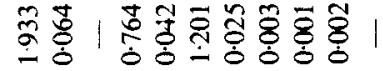

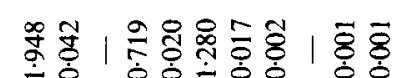
万人ั

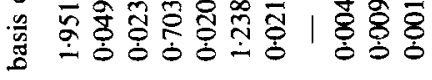

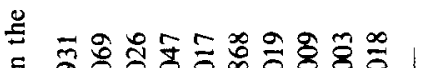

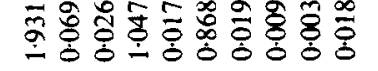

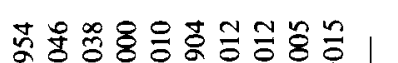

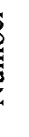

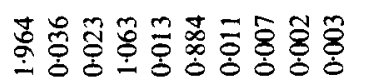

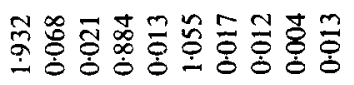

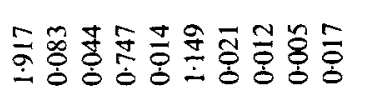

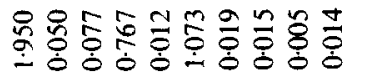

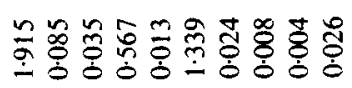

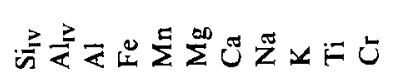

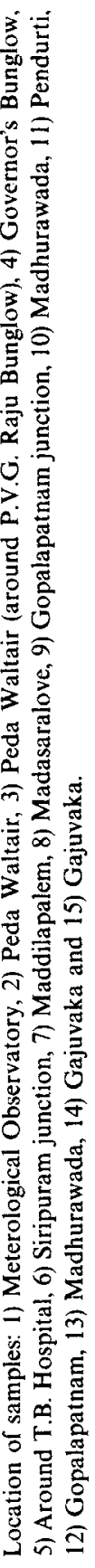




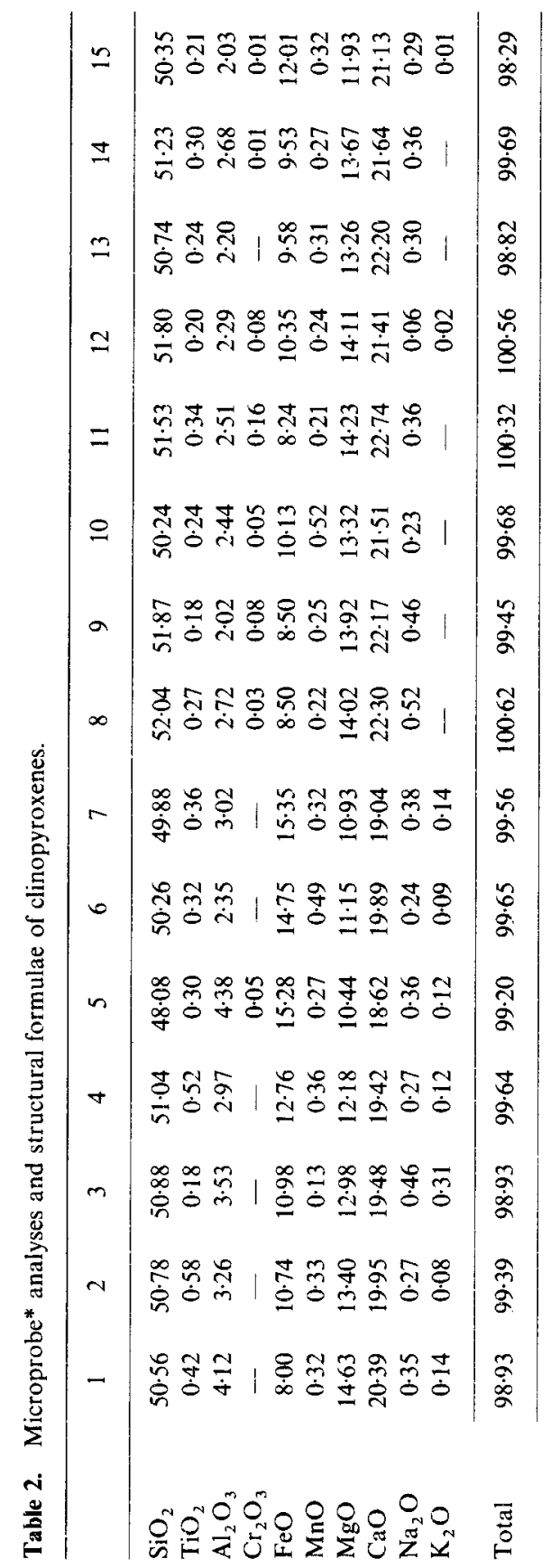

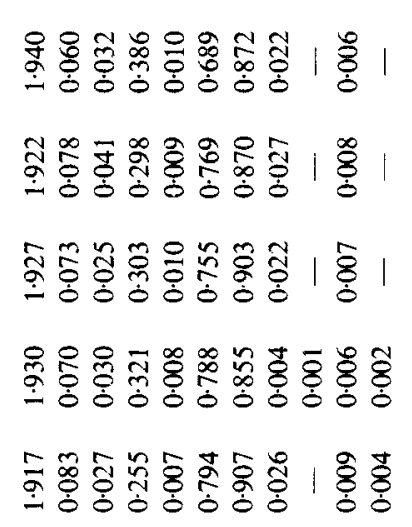

号 号

窟落

焉

5

$80<$

总苋

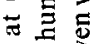

\&

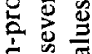

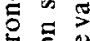

苍导

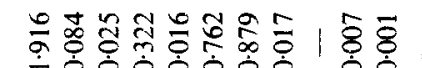

政

密

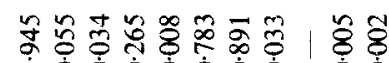

욜 离

舟

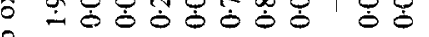

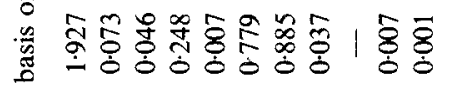

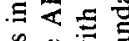

政

要过

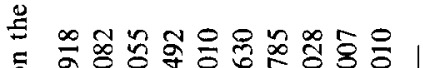

08

我品

产

.

-

政

8 .

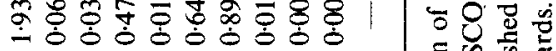

我

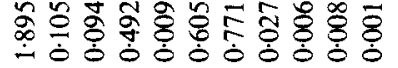

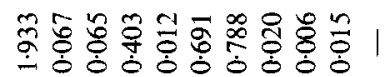

政

0

달

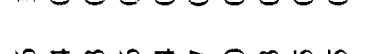

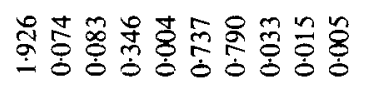

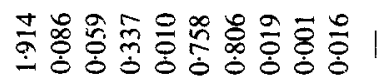

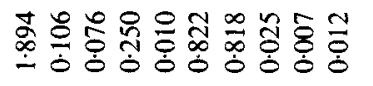

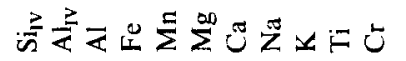

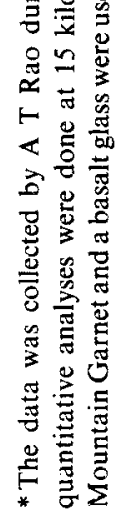




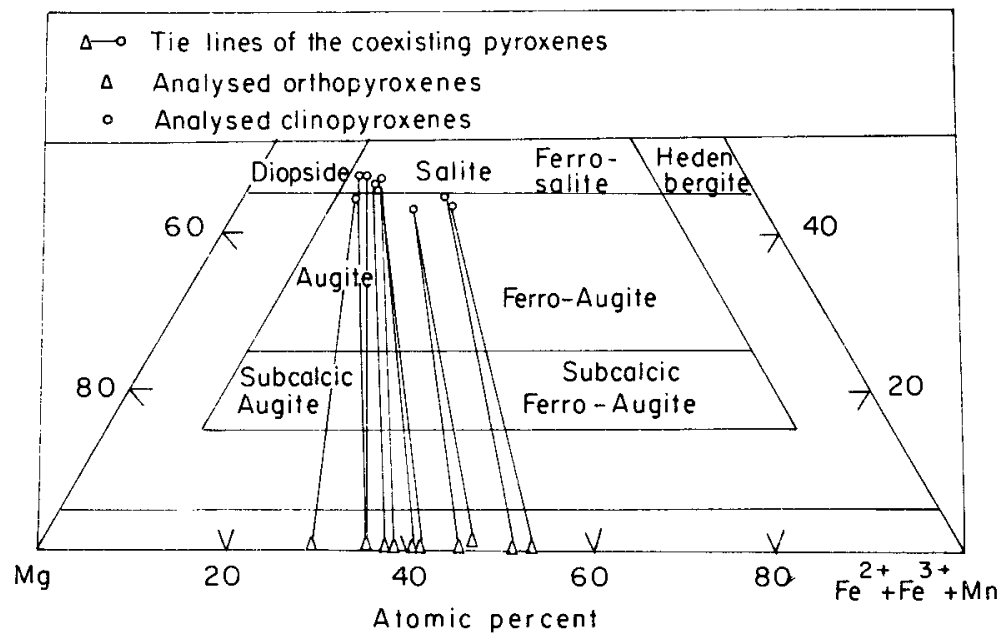

Figure 2. Distribution of pyroxene analysis with respect to $\mathrm{Ca}, \mathrm{Mg}$ and $\mathrm{Fe}^{2+}+\mathrm{Fe}^{3+}+\mathrm{Mn}$ atomic percentages (after Deer et al 1963).

\section{Distribution of $\mathrm{Mg}$ and $\mathrm{Fe}^{2+}$ among coexisting pyroxenes}

Mueller (1960) and Kretz (1961) concluded that ortho- and clino-pyroxenes behave as ideal solid solutions with respect to $\mathrm{Mg}$ and $\mathrm{Fe}^{2+}$ and the distribution coefficient $\left(K_{D}\right)$ is defined by the following equation:

where

$$
K_{D}=\frac{X^{\mathrm{Opx}} \mathrm{Mg}}{1-X^{\mathrm{Opx}} \mathrm{Mg}} \times \frac{1-X^{\mathrm{Cpx}} \mathrm{Mg}}{X^{\mathrm{Cpx}} \mathrm{Mg}}
$$

$$
\begin{aligned}
& X^{\mathrm{Opx}} \mathrm{Mg}=\mathrm{Mg} / \mathrm{Mg}+\mathrm{Fe}^{2+} \text { in Opx and } \\
& X^{\mathrm{Cpx}} \mathrm{Mg}=\mathrm{Mg} / \mathrm{Mg}+\mathrm{Fe}^{2+} \text { in } \mathrm{Cpx}
\end{aligned}
$$

In recent years the study of distribution of $\mathrm{Mg}$ and $\mathrm{Fe}^{2+}$ among coexisting silicate minerals has attained considerable importance, though ortho- and clino-pyroxenes were studied in detail. Kretz $(1961,1963)$ demonstrated that the distribution coefficient $\left(K_{D}\right)$ relating to $\mathrm{Mg}$ and $\mathrm{Fe}^{2+}$ distribution between coexisting ortho- and clinopyroxenes differs between igneous and metamorphic assemblages. Though Bartholome (1962) considered the $\mathrm{Mg}$ and $\mathrm{Fe}^{2+}$ partition coefficient $K_{p}$ in a manner opposite to that of Kretz, the $K_{p}$ values obtained are different for both igneous and metamorphic mineral assemblages.

$$
K_{p}=\frac{\left(\mathrm{F}^{2+} / \mathrm{Mg}\right) \mathrm{Ca}-\text { poor }}{\left(\mathrm{Fe}^{2+} / \mathrm{Mg}\right) \mathrm{Ca}-\text { rich }}
$$

The $\mathrm{Ca}, \mathrm{Mg}, \mathrm{Fe}^{2+}$ and $K_{p}$ values for coexisting pyroxene pairs are given in table 3. The $k_{p}$ values mostly range from 1.5 to 2.0 . The $K_{p}$ values for coexisting pyroxenes (Leelanandam 1967) from charnockite series of Madras and Kondapalli range from 1.7 to $2 \cdot 3$. The $\mathrm{Fe}^{2+} / \mathrm{Mg}$ values of the ortho- and clino-pyroxenes are plotted in the diagram (figure 3) of Bartholome (1962). The values show clustering along the partition coefficient line $K_{p} 1 \cdot 8$, indicative of metamorphic mineral assemblage. 


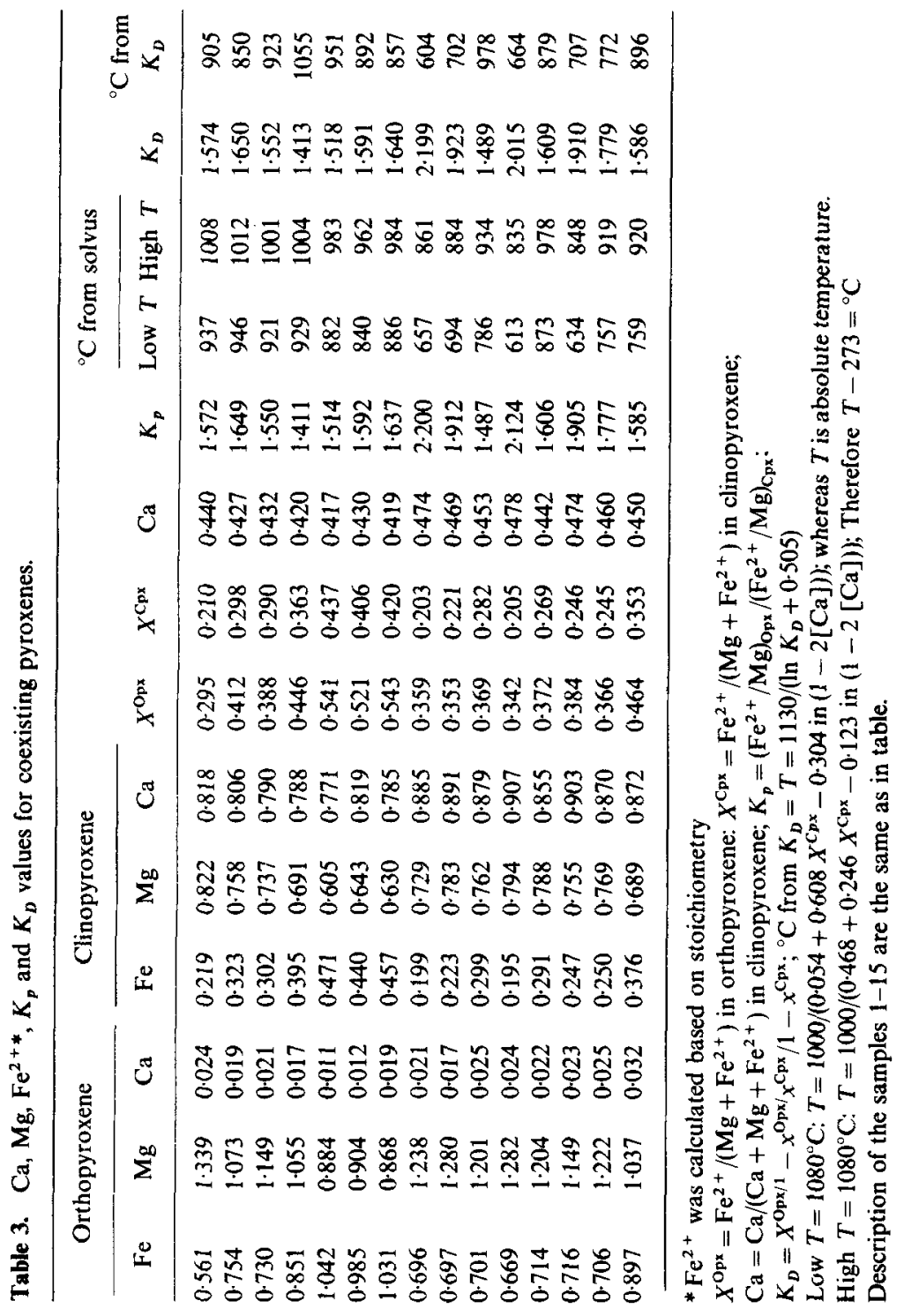




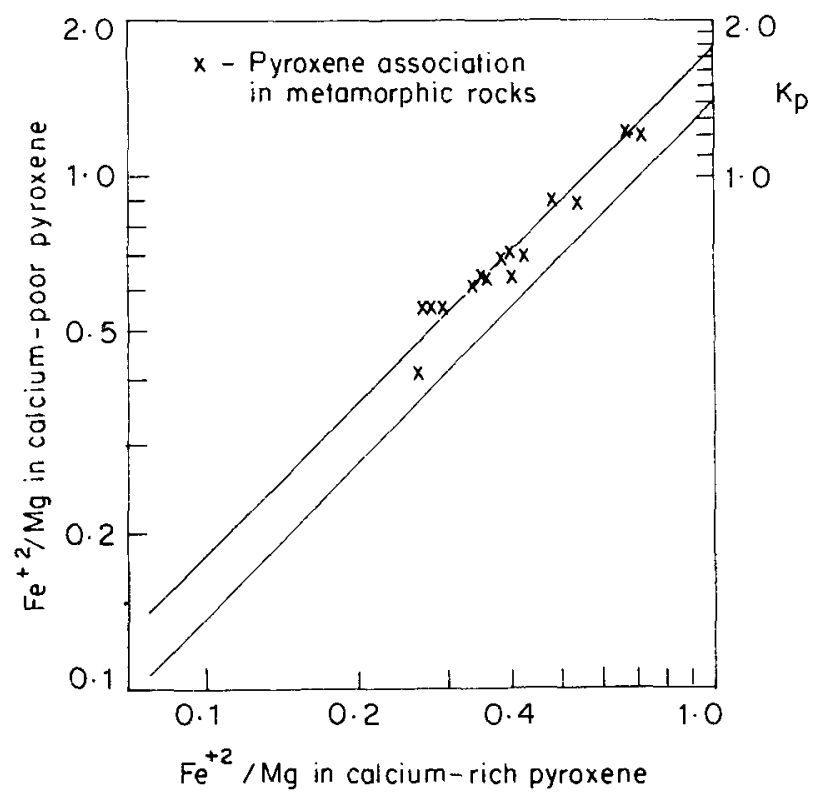

Figure 3. Graphical $\log -\log$ plot indicating the distribution of $\mathrm{Fe}^{2+} / \mathrm{Mg}$ in coexisting pyroxenes (after Bartholome 1962).

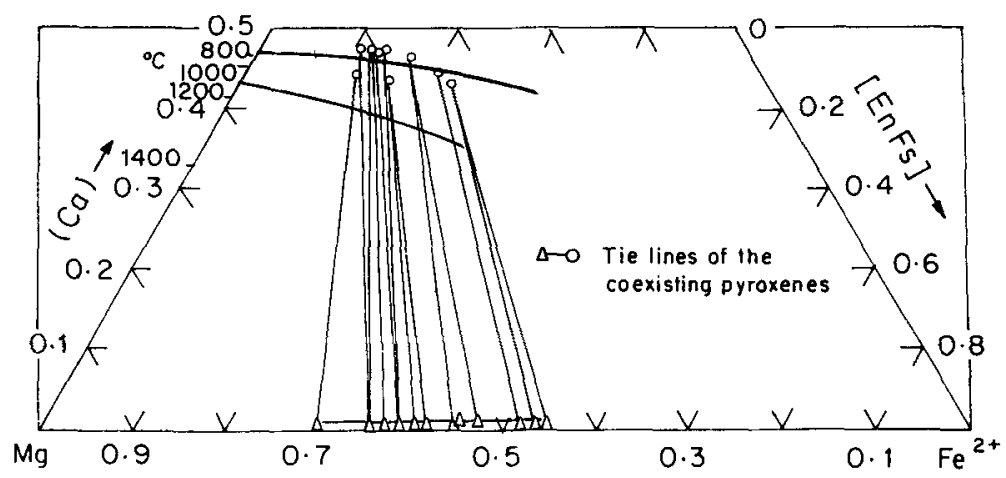

Figure 4. The pyroxene quadrilateral showing associated $\mathrm{Ca}$-rich and $\mathrm{Ca}$-poor pyroxenes from the Visakhapatnam region (after Kretz 1982).

Recent study by Kretz (1982) is found to be much useful in determining the refined distribution coefficient $K_{D}$ and also in establishing the temperature conditions. The $\mathrm{Ca}, \mathrm{Mg}, \mathrm{Fe}^{2+}$ and $K_{D}$ values along with the deduced temperatures (figures 4 and 5) for the coexisting pyroxenes in the pyroxene granulites are given in table 3 . The clinopyroxenes indicate lower temperature (figure 6), perhaps corresponding to the reset values during retrograde metamorphism. The $P-T$ conditions are calculated based on the results of Wood and Banno (1973), Wells (1977), Powell (1978), Bertrand and Mercier (1985) and Fonarev and Graphchicov (1987) and are given in table 4. The data obtained from the methods of Kretz (1982), Wood and Banno (1973), Wells (1977) and Bertrand and Mercier (1985) range from $700-1000^{\circ} \mathrm{C}$ and gave a mean temperature of $850^{\circ} \mathrm{C}$ with an uncertainty in these numbers estimated to be $\pm 150^{\circ} \mathrm{C}$. 


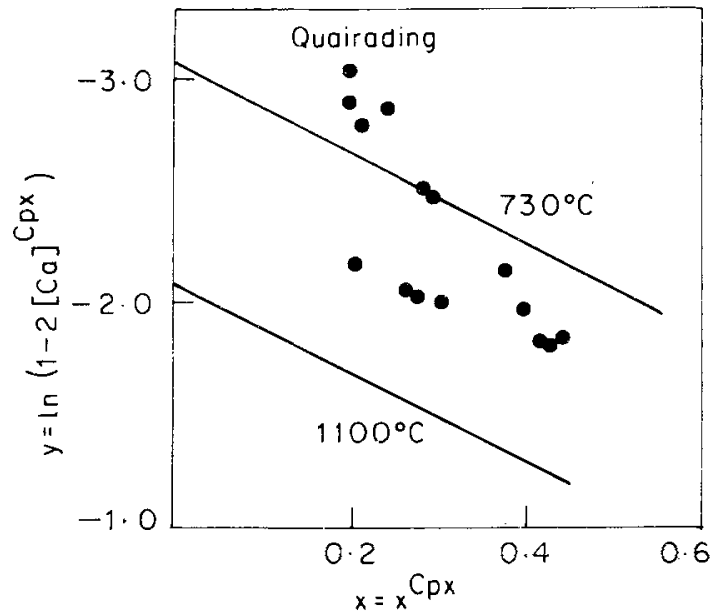

Figure 5. Plot of $\ln \left(1-2 \mathrm{Ca}^{\mathrm{Cpx}}\right)$ vs. $X^{\mathrm{Cpx}}$ for pyroxenes from Visakhapatnam region (after Kretz 1982).

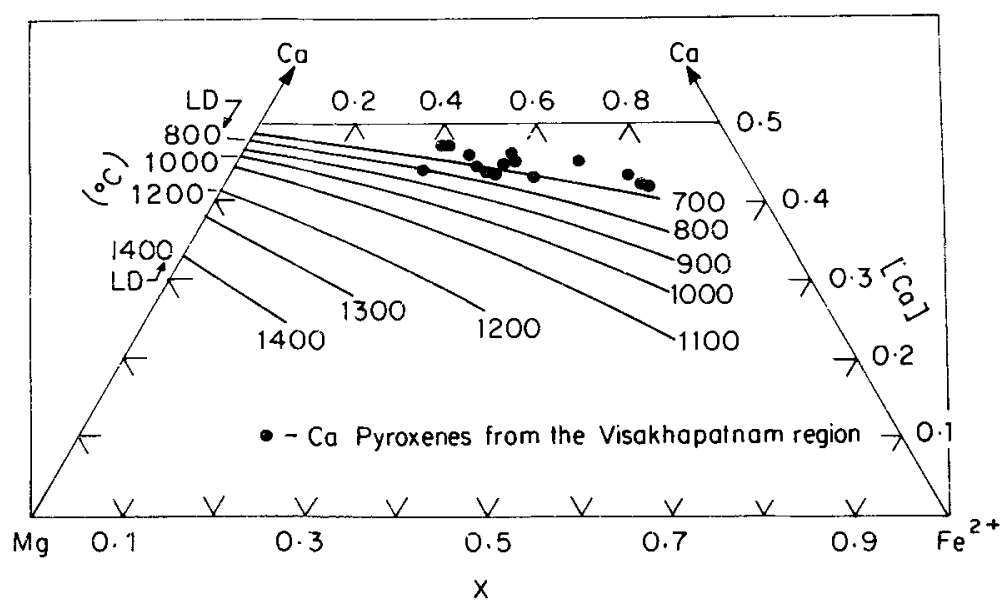

Figure 6. The pyroxene quadrilateral, showing $\left({ }^{\circ} \mathrm{C}\right)$ on the Ca pyroxene slope of the solvus surface (after Kretz 1982).

The other methods of Powell (1978) and Fonarev and Graphchicov (1987) indicate a lower temperature of $750^{\circ} \mathrm{C} \pm 100^{\circ} \mathrm{C}$. Lindsley (1983) reported that the application of his method of pyroxene thermometry to granulites has difficulties but the coexisting pyroxene pairs under study have yielded a range of 600 to $800^{\circ} \mathrm{C}$ using the isothermal, isobaric projections of phase equilibria on the pyroxene quadrilateral (Davidson and Lindsley 1989). The mineralogical thermometers are formulated on the main principle of redistribution of components between coexisting minerals involving experimental studies and modelling of mineral equilibria of solid solutions. However, the accuracy of calibration of thermometers depends more on the reconstruction of primary pyroxene compositions on the basis of textural evidence. The temperature of $750 \pm 100^{\circ} \mathrm{C}$ obtained by the calculations of pyroxene 
Table 4. Estimate of pressure annd temperature values of coexisting pyroxenes.

\begin{tabular}{|c|c|c|c|c|c|c|c|c|}
\hline \multirow{2}{*}{$\begin{array}{l}\text { Method/ } \\
\text { Sample No. }\end{array}$} & \multicolumn{2}{|c|}{$\begin{array}{l}\text { Bertrand and } \\
\text { Mercier (1985) }\end{array}$} & \multicolumn{2}{|c|}{$\begin{array}{c}\text { Fonarev and } \\
\text { Graphchicov (1987) }\end{array}$} & \multicolumn{2}{|c|}{ Powell (1978) } & \multirow{2}{*}{$\begin{array}{c}\text { Wood and } \\
\text { Banno }(1973) \\
T\left({ }^{\circ} \mathrm{C}\right)\end{array}$} & \multirow{2}{*}{$\begin{array}{r}\text { Wells } \\
(1977) \\
T\left({ }^{\circ} \mathrm{C}\right)\end{array}$} \\
\hline & $P(K)$ bar & $T\left({ }^{\circ} \mathrm{C}\right)$ & $P(K)$ bar & $T\left({ }^{\circ} \mathrm{C}\right)$ & $P(K)$ bar & $T\left({ }^{\circ} \mathrm{C}\right)$ & & \\
\hline \multirow[t]{3}{*}{1} & 4.000 & 898 & $4 \cdot 000$ & 815 & 4.000 & 827 & 963 & 993 \\
\hline & 6.000 & 899 & $6 \cdot 000$ & 820 & $6 \cdot 000$ & 834 & & \\
\hline & 8.000 & 900 & $8 \cdot 000$ & 826 & $8 \cdot 000$ & 841 & & \\
\hline \multirow[t]{3}{*}{2} & 4.000 & 875 & $4 \cdot 000$ & 765 & 4.000 & 766 & 925 & 995 \\
\hline & 6.000 & 877 & $6 \cdot 000$ & 768 & $6 \cdot 000$ & 773 & & \\
\hline & 8.000 & 877 & $8 \cdot 000$ & 771 & $8 \cdot 000$ & 781 & & \\
\hline \multirow[t]{3}{*}{3} & 4.000 & 876 & 4.000 & 828 & $4 \cdot 000$ & 770 & 921 & 984 \\
\hline & 6.000 & 877 & 6.000 & 832 & $6 \cdot 000$ & 778 & & \\
\hline & 8.000 & 878 & 8.000 & 837 & 8.000 & 786 & & \\
\hline \multirow[t]{3}{*}{4} & 4.000 & 867 & 4.000 & 795 & $4 \cdot 000$ & 716 & 894 & 967 \\
\hline & 6.000 & 868 & $6 \cdot 000$ & 798 & 6.000 & 724 & & \\
\hline & 8.000 & 869 & $8 \cdot 000$ & 801 & $8 \cdot 000$ & 732 & & \\
\hline \multirow[t]{3}{*}{5} & $4 \cdot 000$ & 825 & $4 \cdot 000$ & 773 & $4 \cdot 000$ & 641 & 869 & 951 \\
\hline & 6.000 & 825 & 6.000 & 775 & 6.000 & 648 & & \\
\hline & $8 \cdot 000$ & 826 & 8.000 & 776 & $8 \cdot 000$ & 655 & & \\
\hline \multirow[t]{3}{*}{6} & $4 \cdot 000$ & 788 & $4 \cdot 000$ & 758 & $4 \cdot 000$ & 676 & 861 & 934 \\
\hline & $6 \cdot 000$ & 789 & 6.000 & 760 & 6000 & 682 & & \\
\hline & 8.000 & 789 & $8 \cdot 000$ & 761 & $8 \cdot 000$ & 687 & & \\
\hline \multirow[t]{3}{*}{7} & $4 \cdot 000$ & 823 & $4 \cdot 000$ & 762 & $4 \cdot 000$ & 734 & 875 & 960 \\
\hline & 6.000 & 823 & 6.000 & 764 & 6.000 & 742 & & \\
\hline & 8.000 & 824 & 8.000 & 766 & 8.000 & 784 & & \\
\hline \multirow[t]{3}{*}{8} & $4 \cdot 000$ & 703 & 4.000 & 683 & $4 \cdot 000$ & 780 & 843 & 854 \\
\hline & 6.000 & 703 & 6.000 & 786 & $6 \cdot 000$ & 782 & & \\
\hline & $8 \cdot 000$ & 704 & 8.000 & 688 & 8.000 & 784 & & \\
\hline \multirow[t]{3}{*}{9} & $4 \cdot 000$ & 696 & 4.000 & 689 & 4.000 & 742 & 832 & 837 \\
\hline & 6.000 & 697 & 6.000 & 692 & 6.000 & 744 & & \\
\hline & $8 \cdot 000$ & 698 & 8.000 & 694 & $8 \cdot 000$ & 746 & & \\
\hline \multirow[t]{3}{*}{10} & 4.000 & 738 & 4.000 & 744 & $4 \cdot 000$ & 828 & 851 & 876 \\
\hline & 6.000 & 739 & 6.000 & 747 & 6.000 & 831 & & \\
\hline & 8.000 & 739 & 8.000 & 750 & 8.000 & 834 & & \\
\hline \multirow[t]{3}{*}{11} & 4.000 & 677 & $4 \cdot 000$ & 665 & 4.000 & 797 & 824 & 827 \\
\hline & 6.000 & 678 & 6.000 & 668 & 6000 & 799 & & \\
\hline & 8.000 & 679 & 8.000 & 670 & 8.000 & 800 & & \\
\hline \multirow[t]{3}{*}{12} & 4.000 & 818 & 4000 & 730 & 4.000 & 815 & 899 & 950 \\
\hline & 6.000 & 819 & 6.000 & 733 & $6 \cdot 000$ & 820 & & \\
\hline & 8.000 & 820 & 8.000 & 736 & 8.000 & 825 & & \\
\hline \multirow[t]{3}{*}{13} & 4.000 & 674 & $4 \cdot 000$ & 682 & 4.000 & 797 & 818 & 835 \\
\hline & 6000 & 675 & 6.000 & 685 & $6 \cdot 000$ & 798 & & \\
\hline & 8.000 & 676 & 8.000 & 687 & 8.000 & 800 & & \\
\hline \multirow[t]{3}{*}{14} & 4.000 & 749 & 4.000 & 719 & $4 \cdot 000$ & 825 & 863 & 890 \\
\hline & 6.000 & 750 & 6.000 & 721 & 6.000 & 825 & & \\
\hline & 8.000 & 751 & $8 \cdot 000$ & 724 & 8.000 & 831 & & \\
\hline \multirow[t]{3}{*}{15} & 4.000 & 672 & $4 \cdot 000$ & 715 & 4.000 & 848 & 802 & 833 \\
\hline & 6.000 & 673 & $6 \cdot 000$ & 717 & 6.000 & 850 & & \\
\hline & 8.000 & 673 & 8.000 & 719 & 8.000 & 852 & & \\
\hline
\end{tabular}




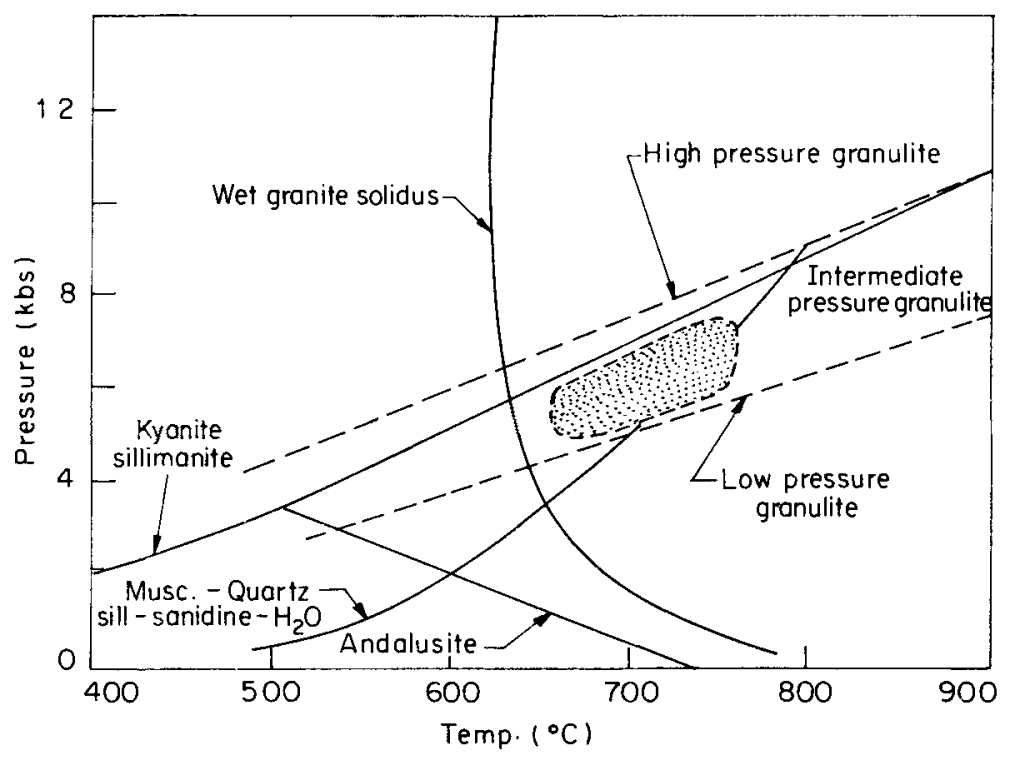

Figure 7. The stippled field indicates the estimated $P / T$ conditions of equilibration of the S.E. Sri Lanka granulites (after Jayawardena and Carswell 1976).

geothermometers given by Powell (1978) and Fonarev and Graphchicov (1987) is preferred because of the overall consistency of the values (table 4).

Similarities in mineralogy and petrology among basic granulites of the Eastern Ghats granulite belt and granulites of Sri Lanka reflect, in general, similar conditions of crystallization of pyroxenes. The regional extension of granulite belt in India and Sri Lanka (Yoshida et al 1990) indicates that the coexisting pyroxenes in basic granulites have attained equilibrium under $P-T$ environment corresponding to intermediate pressure granulites (figure 7).

\section{Acknowledgements}

The authors are grateful to Prof. V I Fonarev of the Institute of Experimental Mineralogy for furnishing the computer-processed $P-T$ data. JUR, AMR and PCSR thank the Council of Scientific and Industrial Research and University Grants Commission, New Delhi for financial assistance.

\section{References}

Bartholome P 1962 Iron-magnesium ratio in associated pyroxenes and olivines; Geol. Soc. Am. Bull., Buddington Volume 1--20

Bertrand P and Mercier J C C 1985 The natural solubility of coexisting ortho- and clino-pyroxenes towards an absolute geothermometer for the natural system; Earth. Planet. Sci. Lett. 76 109-122

Davidson P M and Lindsley D H 1989 Thermodynamic analysis of pyroxene-olivine-quartz equilibria in the system $\mathrm{CaO}-\mathrm{MgO}-\mathrm{FeO}-\mathrm{SiO}_{2} ;$ Am. Mineral. 74 18-30

Deer W A, Howie R A and Zussman J 1963 Rock-forming minerals; 1 ortho- and ring-silicates (London: Longmans) 
Fonarev V I and Graphchicov A A 1987 Physical-chemical petrology (Moscow: Nauka) 14 118-136 (in Russian)

Halden N M, Bowers D R and Dash B 1982 Structural evolution of migmatites in granulite facies terraine, Precambrian crystalline complex of Angual, Orissa, India; Trans. R. Soc., Edin. Earth Sci. 73 109-118

Hess H H 1949 Chemical composition and optical properties of common clinopyroxenes; Part I; Am. Mineral. 34 621-666

Hess H H 1952 Orthopyroxenes of the Bushveld type: Ion substitutions and changes in unit cell dimensions; Am. J. Sci., Bowen Volume 173-188

Howie R A 1955 The geochemistry of the charnockite series of Madras, India; R. Soc. Edin. Trans. 62 725-768

Jayawardena D E Des and Carswell D A 1976 The geochemistry of charnockite and their constituent ferro-magnesium minerals from the Precambrian of Southeast Sri Lanka; Miner. Mag. 40 541-554.

Kretz R 1961 Some applications of thermodynamics of coexisting minerals of varying compositions. Examples: Ortho- pyroxenes - clinopyroxenes and orthopyroxenes-garnet; J. Geol. 69 361-387

Kretz R 1963 Distribution of magnesium and iron between orthopyroxene and clinopyroxene in natural mineral assemblages; $J$. Geol. 71 773-785.

Kretz R 1982 Transfer and exchange equilibria in a portion of the pyroxene quadrilateral as deducted from natural and experimental data; Geochim. Cosmochim Acta. 46, 411-421

Leelanandam C 1967 Chemical study of pyroxenes from the charnockitic rocks of Kondapalli, Andhra Pradesh, India; with emphasis on the distribution of elements in coexisting pyroxenes; Miner. Mag. 36 153-179

Lindsiey D H 1983 Pyroxene thermometry; Am. Mineral. 68 477-493

Mueller R F 1960 Compositional characteristics and equilibrium relations in mineral assemblages of metamorphosed iron formation; Am. J. Sci. 258 581-598

Muir I D 1951 The clinopyroxenes of the Skaergaard intrusion, Eastern Greenland; Miner. Mag. 29 690-714

Paul D K, Ray Barman T, Mcnaughton N J, Fletcher I R and Potts P J 1990 Archaean-Proterozoic evolution of Indian charnockites: Isotopic and geochemical evidence from granulites of the Eastern Ghats belt; J. Geol. $98253-263$

Perraju P, Kovach A and Svingor E 1979 Rubidium-strontium ages of some rocks from parts of the Eastern Ghats of Orissa and Andhra Pradesh, India; J. Geol. Soc. India 20 290-296

Powell R 1978 The thermodynamics of pyroxene geotherms; Philos. Trans. R. Soc. London A288 457-469

Rao A T and Rao P V N 1987 Reaction zones from leptynites of Visakhapatnam, Andhra Pradesh; Geophys. Res. Bull. 25 191-195

Sriramdas A and Rao A T 1979 Charnockites of Visakhapatnam, Andhra Pradesh; J. Geol. Soc. India 20 $512-517$

Yoshida M, Funaki M and Vitanage P W 1990 Justaposition of India-Sri Lanka-Antarctica in proterozoic to mesozoic Gondwana. (eds) Y Hiroi and Y Motoyoshi; in Study of geological correlation between Sri Lanka and Antarctica; Interim report of Japan-Sri Lanka Joint Research 118-131

Wells P R A 1977 Pyroxene thermometry in simple and complex systems; Contrib. Miner. Petrol. 62 129-139

Wood B J and Banno S 1973 Garnet-orthopyroxene and ortho-pyroxene-clinopyroxene relationships in simple and complex systems; Contrib. Miner. Petrol. 42 109-124 